\title{
JEANNE PONTOPPIDAN
}

\author{
AT LASE (MED) DET UBEVIDSTE \\ - OM PSYKOANALYTISK TOLKNING AF LITTERÆRE VERKER
}

Det er min opfattelse, at al den æstetiske lystfølelse, som digteren giver os, har karakter af førlyst og at den egentlige nydelse ved et digterværk skyldes, at det frigør sjælelige spændinger $i$ os.

Sigmund Freud i Digteren og fantasierne (1908)

Da Freud i begyndelsen af dette århundrede fremlagde sine første skrifter om det litterære værk i en psykoanalytisk tolkningsramme, lagde han grunden til en metodisk diskussion, som skulle gøre det muligt at snkue skriveprocessen i dens genese og fungeren. Med hensyn til sammenkoblingen mellem litteratur og psykoanalyse lå der fra Freuds side ikke noget ønske om en tolkning af Litteraturen som sådan betragtet. Derimod havde han intentioner om at bidrage til en afklaring af problemstillinger, han stødte på i sit kliniske arbejde, og i forbindelse med de teoretiske udarbejdelser, han foretog. Som det vil være de fleste bekendt, er denne optik ingenlunde at betragte som en uproblematisk forskningsmanøvre for såvel litteraturteoretikere som psykoanalytikere; derfor vil jeg i det følgende kommentere denne kritik, idet jeg som grundlag anvender to Freud-tekster, nemlig Der Wahn und die Traume in W. Jensens Gradiva (1907) og Der Dichter und das Phantasieren (1908) (1).

I indledningen til sit studium af Gradiva fortæller Freud, at det oprindeligt havde været hans mening kun at analysere de to-tre drømme, som forekommer i novellen, for at få en bekræftelse på sin hypotese om drømmen som en realisation af et ønske (fremlagt i Drømmetydning år 1900). Freud havde ingen skrupler med hensyn til at analysere de af Wilhelm Jensen opdigtede drømme på linie med rigtige drømme, idet det var hans udgangs- 
punkt, at der i forfatterens litterære virksomhed spillede de samme mekanismer ind fra det ubevidste, som allerede sås ved drømmeaktiviteten.

Gradiva handler om Norbert Hanold, en temmelig farveløs og genert ung amatørarkæolog, der under et besøg i Vatikan-museets oldtidssamling bliver forgabt i et romersk stenrelief, der forestiller en ung gående kvinde. Han kalder hende Gradiva, hvilket betyder "hende der stråler, når hun går". I sit arbejdsværelse hænger han en kopi af dette relief, og efterhånden fascineres han $i$ den grad af den afbildede kvinde - i særdeleshed af hendes gang. Efter en mareridtsagtig drøm, hvor han ser Gradiva i Pompei, den dag byen bliver udslettet af Vesuvs lava, giver han sine fantasmer (2) frit løb. Han sørger over hendes død, som om det drejede sig om hans elskede og ikke en ukendt kvinde, der mistede livet år 79 i Pompei. Helt i sine fantasmers vold drager han til Italien for at finde sin Gradiva, og en dag på gaden i Pompei mener han at genkende hende. Den kvinde, han ser, er imidlertid ganske levende og er ingen anden en hans gamle barndomsveninde Zoë Bertgang, som han engang elskede, men "kom til at glemme" for at kunne hellige sig sin karriere. Bertgang betyder på tysk det samme som Gradiva på latin: hende der stråler, mens hun går, og da Zö̈ (= den levende) bliver klar over, at hun blot er et "livløst" fantasme for Norbert, hjælper hun ham til en gen-kendelse af hende som barndomsveninden Zoe og til en accept af, at hun er den egentlige genstand for hans lidenskab. Norberts fantasmer opløses, og realiteten har sejret.

Som ovenfor nævnt bekymrede det ikke Freud at sammenstille opdigtede drømme med faktiske. Den samme holdning indtager han også, når det gælder inddragelsen af den psykoanalytiske metode $i$ litteraturanalysen. Thi i egentlig forstand er der både i den kliniske analyse og $i$ det litterære værk tale om kommunikation af et budskab. I det psykoanalytiske rum konfronteres analytikeren med analysandens frie associationer, som han eller hun besvarer med en lytten, eventuelt en gentagelse af og til af analysandens udsagn. Kun sjældent interveneres der med en direkte tolkning fra analytikerens side. Den "gleichschwebende Aufmerksamkeit" (3), som Freud benævner den "flaksende", flydende lytten, analytikeren betjener sig af, udgør den tavse intervention, som er med til at få analysandens begær til at komme til syne i talen. Thi sproget, såvel det verbale som det kropslige (gestus, hoste, sukken, gråd osv.), bærer de latente betydninger i analysandens tale, hvorved der gives adgang til det ubevidste. Og det er netop denne metode, den flaksende, flydende opmærksomhed, som Freud benytter ved sin læsning af Gradiva. Den manifeste tekst erstattes med en parafraserende gen-"skrivning"/læsning af fortællingen og indtager derved en forklarende funktion, der bygger teksten op på ny uden at forråde den. En anderledes logik udskiftes således ved den resumerende, parafraserende læsnings dekonstruktion, og dette muliggør en læsning af det ube- 


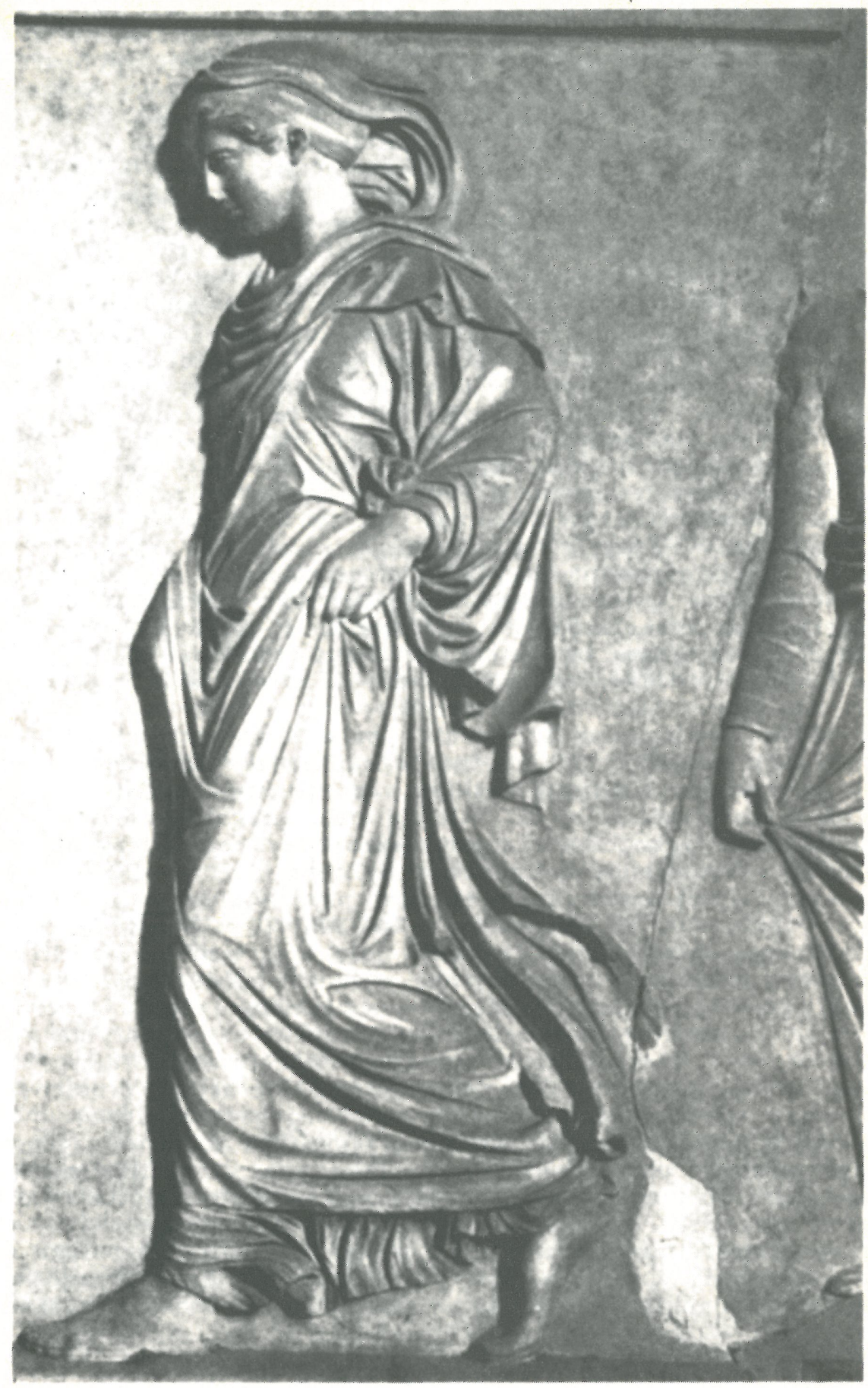


vidste. I Norberts tilfælde er der tale om en manifestation af den sammenhæng, der er mellem hans ubevidste og hans fortrængte ønsker/forestillinger. Freud fremlægger her sin teori om fortrængningen og viser den sammenhæng, der er mellem det fortrængte og det ubevidste.

Norbert har fortrængt erindringen om barndomsveninden og udvikler på bekostning heraf et symptom, der træder i stedet for det ubevidste $\varnothing n s k e$ om en forening med hende. Begærets signifiant (dvs. betydningsbærer) er omformet til symptom (som Lacan ville udtrykke det i smuk forlængelse af Freud). Men fordi symptomet er et kompromis mellem fortrængning og ønske, har betydningen mulighed for at komme til syne i det sproglige udtryk, båret af en signifiant; og det er netop, hvad Zoë udvirker ved a.t få Norbert til at tale og til at reagere på hendes gestus: den måde, hun bevæger sig på̀, mens hun indimellem gentager hans udsagn. Freud udnævner hende til en begavet analytiker. Og sandt er det, at "analysen". lykkes. Det fortrængte bliver bevidst, symptomet opløses - og Zö kan indtage Gradivas plads.

Det interessante er, at Freud ikke ønsker at tage hensyn til novellens undertitel: en "Fantasi". I sit studium nævner Freud, at han ikke ville have haft det ringeste imod, at Jensen som undertitel havde benævnt novellen "et psykiatrisk studium", fordi "forfatteren har udført et fuldstændig korrekt psykiatrisk studium $i$ overensstemmelse med vores opfattelse af sjælelivet. Han har skildret en sygdoms og helbredelseshistorie for at få os til at forstå visse fundamentale principper i den patologiske sjælelære" (op. cit. pp. 42-43) (min oversættelse).

Freuds fremlæggelse af Gradiva er et fint og gennemtørt eksempel på, hvorledes det litterære værk kan betragtes som et psykisk fænomen, en tvetydig diskurs, der illustrerer flere aspekter i den psykoanalytiske teori. Tilbage står spørgsmålet om den kritik, der foreligger både fra psykoanalytikere og litteratur/tekstteoretikere vedrørende brugen af psykoanalysen på ikke-kliniske felter. Det forekommer indlysende, at psykoanalysens problemstillinger ikke kun er relevante i en analytisk praksis, al den stund begge felter driver parallel forskning med hensyn til den menneskelige adfærd, eller sagt på en anden måde: psykoanalysen beskæftiger sig med spørgsmålet om subjektets sandhed i en miskendelsens struktur, som de ubevidste fantasier udfylder. Det litterære værk trækker på disse samme ubevidste fantasier i sin flertydighed. Altså er det de ubevidste fantasiers problematik, som udgør fundamentet mellem litteratur-og psykoanalysen.

Men er det litterære værk netop ikke en censureret gennemog gen-skrevet tekst, hvorfor den ikke kan sidestilles med den analytiske diskurs? spørger den franske psykoanalytiker André Green (4). Hertil kunne man foreløbig svare, at det vel ofte er sådan, at forfatteren på trods af talrige bearbejdninger ikke ved mere om sin litterære aktivitet eller diskurs end analysanden om sine drømme. Eksempelvis gav Wilhelm Jensen $i$ en brevveksling 
med Freud udtryk for, at han accepterede hovedlinierne i Freuds Gradiva-læsning, omend han ikke var i stand til at svare på Freuds spørgsmål vedrørende hans egen personligheds placering i novellen og oprindelsen til den fremlagte tematik. I tilknytning hertil kan siges, at Freuds intense studier af sine "ofres" biografi med henblik på en retfærdiggørelse og realisation af hans teoretiske studier af kunstneriske aktiviteter sagtens kunne have været udeladt. Den særlige læsningsmetode, som han betjente sig af, kunne fint fungere uden disse informationer, thi hans parafraserende læsning viser selv sporene til det ubevidstes sted. Aret efter Gradiva-analysens fremkomst udkommer Der Dichter und das Phantasieren (.1908). Et lille, men yderst fortættet skrift, hvori Freud udfolder den indsigt, han havde givet udtryk for $i$ sin læsning af Jensens novelle med hensyn til opfattelsen af den litterære tekst som en forvrænget manifestation af ubevidste fantasier. På ganske få sider lykkes det Freud via en causerende fremstilling af sammenhængen mellem kunstnerisk aktiv leg og ubevidste fantasmer at løfte den psykoanalytiske tekstfortolkning ind $i$ udsigelsesfeltets komplicerede struktur og herfra videre til en inddragelse af læseren som den katalyserende instans for det litterære værks affektive og erkendelses(miskendelses)mæssige effekt. Disse to optikker hører selvfølgelig sammen, idet værkets effekt fremkommer, når udsigelsesstrukturen og udsagnsforløbet $i$ en favnende tête-à-tête åbner for det læsende subjekts kannibalistiske identifikations-lyst. For lysten må også med i Freuds konstruktion. Både som positiv og negativ lyst. Negativ, som ulyst, når der er tale om en udveksling af "dagdrømmeriske" holden-skjult-for-andre fantasier, ja Freud taler ligefrem om, at den slags fantasier frastøder os. Hvorimod lysten på lystelig vis kan installere sig hos læseren, når der sker en iscenesættelse, en forvrængning af den ubevidste fantasi $i$ en symbolsk realisation, som den litterære tekst repræsenterer. Denne lyst, som forfatteren kan fremkalde hos sin læser, benævner Freud "forlokkelsespræmie" eller "førlyst" og definerer den som "den rent formelle, æstetiske nydelse, fremstillingen af fantasierne tilbyder os" (op. cit. p. 30). Estetisk nydelse vil her sige tekstens udtryksmæssige og formelle egenskaber. Og hermed åbnes for en fornemmet indsigt af stilens, skriftens betydning $i$ en psykoanalytisk læsning. Med denne tekst har Freud kortlagt linierne i det forskningsfelt, som psykoanalysen og litteraturen kan etablere.

André Green stillede spørgsmålet om, hvorvidt den litterære og den psykoanalytiske diskurs ikke var inkompatible størrelser. Med den freudske udfoldelse af forholdet mellem det fortrængte og det ubevidste og dermed af parallellen mellem drømmearbejdet og primærprocessens funktion, med forskydningen og fortætningen som de grundlæggende retoriske operationer (hvilket, som vi har set, implicerer en udarbejdning af stilfigurer og retoriske operationer $i$ tolkningsarbejdet) og dermed også understregningen af, at læseren skaber tekstens betydning ud fra det formernes spil, 
som skriften, forfatterens stil indstifter, ja så kan vi svare dr. Green, at netop ved at tage udgangspunkt i den litterære tekst som en forvrænget, censureret og gennembearbejdet fremlæggelse af ubevidste fantasier vil begærets signifianter, som de fantasmatiske investeringer de er, trænge sig på uden om symptomet. Skriften må ikke forvises til fordel for talen. Sproget er analysens priviligerede instrument i det forskningsfelt, som handler om (u)bevidsthedens funktion og genese. Ikke i en vulgær simplificerende overføring, men med hjælp fra den strukturelle lingvistik, semiotikken og skrifttænkningen kan vi applicere den analytiske tolkning, på det litterære værk. Forbindelsen mellem litteratur og psykoanalyse bliver således signifiant'ens vidensfelt, og afsluttende kan vi konkludere, at Freuds fortjeneste er at have defineret et nyt forskningsfelt, et nyt sted, hvor det blev muligt at uddybe erkendelsen af den psykiske instans $i$ en læsning af det ubevidste. Freud forstod at indstifte en dialog med forfatteren $i$ en begærende omfavnelse uden at fortabe sin egen position $i$ kommunikationen.

PS. Det turde være klart, at Lacan huserer henover og nedenunder disse kommentarer... men dette implicerer ikke en fordunkling af Freud. Snarere en profilering af hans tanker omkring litteratur og psykoanalyse.

\section{NOTER:}

1) Begge tekster er hentet fra S. Freud: Bildende Kunst und Literatur Studienausgabe Band $X$ (Fischer Verlag 1969). Kun den sidstnævnte tekst findes i dansk oversættelse in J. Dines Johansen: Psykoanalyse, litteratur, tekstteori bd. 1 (Borgen 1977).

2) Fantasi er den danske oversættelse af den tyske term Phantasie, men da "fantasi" dækker et langt bredere betydningsfelt end den psykoanalytiske signifiant kan bære, benyttes den franske term "fantasme", subsidiært "ubevidst fantasi".

3) Begrebet beskrives for første gang af Freud i Traumdeutung (1900) (Studienausgabe bd. 1-2), uden at Freud dog benævner den "gleichschwebende Aufmerksamkeit". Kommenteres bl. a. indgånde $i$ artiklen Ratschläge für den Arzt bei der psychoanalytischen Behandlung (1912) (Studienausgabe Ergänzungsband).

4) André Green: Un oeil en trop: Les Complexe d'Oedipe dans la tragédie, 1969, pp. 30-31. 